\title{
Description of Drug Pricing and Procurement Information Web Portals in Some Latin American Countries
}

\author{
Angela Acosta ${ }^{1 *}$, Sergio Basto ${ }^{2}$, María Fernanda Fonseca ${ }^{3}$, Carlos Durán ${ }^{3,4}$, Claudia Vargas ${ }^{1}$ and Joan Rovira $^{5}$ \\ ${ }^{1}$ Fundación IFARMA, Colombia \\ ${ }^{2}$ School of Government Alberto Lleras Camargo, University of Los Andes, Colombia \\ ${ }^{3}$ Heymans Institute of Pharmacology, Ghent University, Belgium \\ ${ }^{4}$ Ecuatorian Center for Clinical \& Health Information, Assessment and Research (CIEC), Yachay Public Company, Ecuador \\ ${ }^{5}$ University of Barcelona, Spain
}

\begin{abstract}
Background: This study aims to characterize the sources of information on pricing and public procurement available in some Latin American countries, in order to facilitate the development of comparative studies in the region and the implementation of pharmaceutical policies such as price regulation.

Methods: Description of the sources of information in terms of web portals characteristics, general characteristics of information, characteristics of pricing data and drug public procurement data.

Results: The sources of information described are Brazil's Health Price Database (BPS), the Brazilian Drug Market Regulation Chamber (CMED), the Chilecompra Public Procurement Portal, the Mexican Social Security Institute (IMSS) Procurement Portal, Panamácompra Public Procurement Portal, Argentina's K@iros portal, the Peruvian Pharmaceutical Products Observatory (OPFP), the National Public Procurement Service of Ecuador (SERCOP) and the Drug Price Information System of Colombia (SISMED). Eight of the nine portals belong to governmental entities such as ministries, public procurement centers or drug regulatory agencies. Portals such as the BPS provide visibility and transparency. Thus, each public institution exercises its role of social control and surveillance of the public administration. Other sectors of society are also benefited and use the information available for various consultations and studies. Commercial transactions data on open access websites more accurately account for the national drug volume and expenditure than other sources.

Conclusions: The characterization carried out enhances the transparency of information on prices and public procurement of medicines to contribute to the decision-making of Latin American governments regarding negotiations for the purchase of pharmaceutical products, fixing and building international reference prices and adjusting prices of already regulated medicines, as well as the consumption of this information for the development of drug use studies.
\end{abstract}

Keywords: Medicines pricing; Medicines public procurement; Phrmaceutical pricing policy; Pharmaceutical policy; Medicines prices data; Medicine; Pharmaceutical procurement data

Abbreviations: BPS: Health Price Database Brazil; CATMAT: National Medicine Code, Brazil; CMED: Drug Market Regulation Chamber, Brazil; CIMLAC: Network of Medicines Information Centers of Latin America and the Caribbean; DURG LA: Drug Utilization Research Group, Latin America Eurodurg European Drug Utilization Research Group; ISPE: International Society for Pharmacoepidemiology; IMSS: Social Security Institute, Mexico; LA: Latin America; OPFP: Peruvian Pharmaceutical Products Observatory, Peru; SERCOP: National Public Procurement Service, Ecuador; SIASG: Public Procurement Integrated General Services Administration System, Brazil; SISMED: Drug Price Information System, Colombia.

\section{Introduction}

The growing demand for health services and the limited financial resources available to governments, among others, make it necessary to implement strategies and management mechanisms that maximize the health benefits of the population [1].

One of the strategies implemented in order to contain or curb pharmaceutical expenditure in several countries is drug price regulation; price regulation policies of international reference are those that may have more evidence of results and impact. In European countries and Canada, medicines expenditure was reduced by a third as a result of the induced greater use of lower-cost drugs by the implementation of this type of interventions [2]. In Colombia, the implementation of price regulation through reference prices since 2013 has resulted in an average reduction of $41 \%$ in the prices of drugs that represents $80 \%$ of expenditure on medicines not included in the national benefit plan [3].

Despite these positive results mentioned, there are important challenges to the design and comparative analyses of prices. Firstly, the international reference price system has led to reduced transparency and accessibility of drug price information as companies try to prevent countries from knowing that the same product is being sold at a lower price in another country and claiming that same price. In addition to the above, Danzon et al. [1] and Machado et al. [4] mention that most studies comparing drug prices between countries have shown bias due to methodological problems, particularly related to the lack of comparability of drug price information sources.

Several drug price reporting web portals have been emerging in

*Corresponding author: Angela Acosta, Fundación IFARMA, Colombia, Tel: + (+571) 3381490; E-mail: apacostas@unal.edu.co

Received May 15, 2018; Accepted May 22, 2018; Published May 29, 2018

Citation: Acosta A, Basto S, Fonseca MF, Durán C, Vargas C, et al. (2018) Description of Drug Pricing and Procurement Information Web Portals in Some Latin American Countries. Pharmacoeconomics 3: 116. doi:10.4172/2472-1042.1000116

Copyright: $\odot 2018$ Acosta A, et al. This is an open-access article distributed under the terms of the Creative Commons Attribution License, which permits unrestricted use, distribution, and reproduction in any medium, provided the original author and source are credited. 
recent years. Despite large availability of information, the quality of websites and data disclosed therein is still uncertain. Both in the European and in the Latin American context, different information for the same drug have been found between countries $[5,6]$.

The comparability of drug price information sources may be compromised by factors associated with data collection methodology, the context in which data is collected and the way in which the source shows the information. In the case of the information collection methodology, aspects such as the stakeholder of the drug distribution chain to which price corresponds and the technical description of the product to which price corresponds (composition, pharmaceutical form, dosage, concentration, type of packaging and commercial presentation) data collection frequency and collected data quality control measures to avoid inconsistencies are included [4-7].

Regarding the context, aspects such as health system organization, entities' contracting and purchase conditions (volume of units, payment conditions and special discounts) can be highlighted. Finally, aspects related to the way data are presented in the sources of information include the possibility of access (public, partially restricted or totally restricted), registration requirement (paid or free of charge), the type of price data shown (raw data, average price, information update frequency, search mechanisms, among others) $[5,6,8]$.

Recent publications estimate that the availability of price information sources in countries in the region is small, and that existing ones may be more widely used. In this context, it is useful to generate evidence that describes and sorts the sources of information found in Latin America, starting with those that show greater availability and potential use (Acosta, 2014). This study aims to characterize price information sources available in some Latin American countries in order to facilitate the development of comparative studies in the region.

\section{Methods}

In this paper, the sources of information were defined as databases financed by public or private funds, which may be owned by governmental bodies or health service providers and contain drug price data and/or expenditure representing part of or the whole population of a country [9].

The EuroDURG (2011) methodology was used as the basis for the identification of drug pricing information portals. Messages were sent via e-mail requesting information on sources of information available to the discussion lists of specialized networks on the subject of access and rational use of medicines in Latin America: DURG LA (Drug Utilization Research Group, Latin America), CIMLAC (Network of Medicines Information Centers of Latin America and the Caribbean) and ISPE (International Society of Pharmacoepidemiology, Latin America Chapter).

A list was first designed based on the works of Van Dongen [5], Domínguez \& Iñesta [10] and Acosta [6] to define realms and attributes that would be considered in the characterization of web portals and the information contained therein. A discussion in which authors participated with collaborating external experts in the topic of drug prices, using the consensus technique to validate the list. The final list of realms and attributes considered in this study for the characterization of websites is described in Table 1 and for the characterization of the general information in Table 2.

For the collection of information, tools for characterizing web portals, price information and for public procurement of medicines transactions were designed using several previous references [5,11,12]. Given the particular characteristics of the region, it was necessary to adapt and rely on the technical criteria of authors. Data was collected independently by two researchers. Inconsistencies were settled by a third researcher.

\begin{tabular}{|c|c|c|}
\hline \multicolumn{3}{|c|}{ Website characterization } \\
\hline Realm & Attributes & Criterion \\
\hline \multirow{5}{*}{$\begin{array}{c}\text { Transparency and lack of conflicts of } \\
\text { interest }\end{array}$} & Web portal author & Yes / No \\
\hline & Funding source & Yes / No \\
\hline & Mission objectives of the portal & Yes / No \\
\hline & Webmaster or portal administrator contact & Yes / No \\
\hline & Scope of the portal & Open \\
\hline \multirow{2}{*}{ Access to information } & Access fee or payment & Yes / No \\
\hline & Registration for access & Yes / No \\
\hline \multirow{3}{*}{$\begin{array}{l}\text { Access to price } \\
\text { / transaction data }\end{array}$} & Clicks required to access price information / purchase transaction & $\begin{array}{c}\text { Less than } 5 \text { Clicks / Between } 5 \text { and } 10 \text { Clicks } \\
\text { / More than } 10 \\
\text { Clicks }\end{array}$ \\
\hline & $\begin{array}{l}\text { Search for data within price information / purchase } \\
\text { transaction }\end{array}$ & Yes / No \\
\hline & $\begin{array}{l}\text { Downloading or printing price information / purchase } \\
\text { transaction }\end{array}$ & Yes / No \\
\hline \multirow{2}{*}{ Information update } & Date of last update of the web portal & Yes / No \\
\hline & Update of reported information & $\begin{array}{c}\text { More than a year ago / Between six and } \\
\text { twelve months / } \\
\text { Between one and six months }\end{array}$ \\
\hline \multirow{6}{*}{ User- friendliness } & Availability of an internal search engine & Yes / No \\
\hline & Counter of visits or statistical data of visits & Yes / No \\
\hline & Multilingual website & Yes / No \\
\hline & Website with advertising & Yes / No \\
\hline & Requires specific platforms and browsers to use the website & Yes / No \\
\hline & Users may submit reviews on the website & Yes / No \\
\hline
\end{tabular}

Table 1: Realms and attributes considered in the characterization of web portals. 
Citation: Acosta A, Basto S, Fonseca MF, Durán C, Vargas C, et al. (2018) Description of Drug Pricing and Procurement Information Web Portals in Some Latin American Countries. Pharmacoeconomics 3: 116. doi:10.4172/2472-1042.1000116

Page 3 of 10

\begin{tabular}{|c|c|c|}
\hline \multicolumn{3}{|c|}{ Characteristics of price data and transactions of public procurement } \\
\hline Realms & Attributes & Criterion \\
\hline \multirow{4}{*}{ General information } & Purpose of collecting information & Financing / Distribution / Dispensation / Prescription \\
\hline & $\begin{array}{l}\text { Sector of the distribution system } \\
\text { to which the information belongs }\end{array}$ & Public / Private / Reports both sectors / Not identified \\
\hline & Use of medicines scope & Hospital / Outpatient / Mixed \\
\hline & Requirements for users who enter information & Requires Registration / No Registration Required / Not Applicable \\
\hline \multirow{5}{*}{ Characteristics of price data } & Nature of the collected price data & $\begin{array}{l}\text { Suggested price to the public / Maximum retail price / Institutional purchase price / } \\
\text { Manufacturer's maximum selling } \\
\text { price / Maximum reimbursement values / Wholesaler price / Other - Which (open question) }\end{array}$ \\
\hline & $\begin{array}{l}\text { Nature of the price reported on } \\
\text { the portal }\end{array}$ & $\begin{array}{l}\text { Average Price / Maximum Price / Minimum Price / Suggested } \\
\text { Retail Price / Regulated Price - Which (open question) }\end{array}$ \\
\hline & Price data dates format & Standardized / Non-standardized / Data not reported \\
\hline & Reported price frequency & Monthly / Quarterly / Annual / Variable / Not reported \\
\hline & $\begin{array}{l}\text { Drug standardization and } \\
\text { identification }\end{array}$ & $\begin{array}{l}\text { Drug name / Description of the pharmaceutical form / } \\
\text { Description of drug concentration / Amount of product per commercial presentation }\end{array}$ \\
\hline \multirow{8}{*}{$\begin{array}{l}\text { Characteristics of Public } \\
\text { Procurement Transaction } \\
\text { Data }\end{array}$} & Nature of the transaction data collected & $\begin{array}{c}\text { Public institutional purchase / Private institutional purchase / Others - Which (open } \\
\text { question) }\end{array}$ \\
\hline & Nature of the price reported on the portal & $\begin{array}{c}\text { Unit value (price) per concentration - pharmaceutical form - container - amount contained / } \\
\text { Value (price) per concentration - pharmaceutical form - container - amount } \\
\text { contained / Others - Which (open question) }\end{array}$ \\
\hline & Purchased volume & Purchased volume reported / Purchased volume not reported \\
\hline & Date of purchase award & Date reported / Date not reported \\
\hline & Purchase mechanism & Mechanism reported / mechanism not reported \\
\hline & Buyer's Information & Reported / Not reported \\
\hline & $\begin{array}{l}\text { Information about the supplier to } \\
\text { whom the purchase was awarded }\end{array}$ & Reported / Not reported \\
\hline & Drug standardization and identification & $\begin{array}{l}\text { Drug name / Description of the pharmaceutical form / Description of drug concentration / } \\
\text { Amount of product per commercial presentation }\end{array}$ \\
\hline
\end{tabular}

Table 2: Realms and attributes considered in the characterization of the information available in portals.

\section{Results}

The following web portals were included in the study: Brazilian Health Price Database (BPS) (BPS), Medicines Price Information System of Colombia (SISMED), Chilecompra Public Procurement Portal, the Mexican Social Security Institute (IMSS) Procurement Portal, the PanamáCompra Public Procurement Portal, the Brazilian Medicines Market Regulation Chamber (CMED), the Peruvian Pharmaceutical Products Observatory (OPFP), Argentina's K@ iros portal and the National Public Procurement Service of Ecuador (SERCOP) in Ecuador. Eight of the nine databases analyzed were found to belong to governmental entities such as ministries or public procurement purchasing centers (Table 3 ).

\section{Characterization of web portals}

The results of websites' characterization are described in Table 4. In the case of the realm of "transparency and conflicts of interest", it is emphasized that most portals provided their mission objectives, albeit with different levels of detail. In addition, it was identified that all web portals, except for the K@iros ${ }^{\circledR}$ portal, indicate the entity or institution responsible for the portal; and all reported a contact of the web administrator. On the other hand, no site provided information on its funding source, although most are public and therefore their funding is inferred, which is not the case of K@iros Argentina (Table 4).

Five portals collect information related to the funding and distribution of medicines, while the others only collect information on the distribution process (Table 4). Sites such as Chilecompra, Panamácompra and IMSS collect information only from the public sector and the others do so for both sectors; K@iros does not report this attribute. On the other hand, it is observed that all sources of information include medicines for both inpatient and outpatient use (Table 5).
Transparency and lack of conflicts of interest: The application of the instructions for the characterization of information of prices and public procurement of medicines determined that, in most of the sources, access to information is partially public. Four of the nine belong to a regulatory authority (BPS, CMED, OPFP, SISMED), four to public procurement portals (Chilecompra, IMSS, Panamácompra, SERCOP), and one is a price catalog collected by survey with manufacturers (K@ $\left.\operatorname{iros}^{\otimes}\right)$.

Mission objectives allow the establishment of three main purposes in this second level of information: to promote transparency in public procurement in general, including medicines procurement (BPS, ChileCompra, IMSS, and PanamáCompra), market medicines price monitoring and/or regulation (CMED, OPFP and SISMED) and to promote increased savings in national medicines purchases (SERCOP).

Furthermore, it was identified that web portals indicated the authorship and the responsible bodies (eight governmental entities) with the exception of portal K@iros ${ }^{\oplus}$; all listed a web administrator contact.

On the other hand, no site provided information on its funding source, although eight of the nine sites analyzed belong to governmental entities such as ministries, public purchasing centers, or drug regulatory agencies (Table 4).

Access to information: Given the nature of public access of this level of information, no case requires payment or registration to access the information portal. Tables 4 and 5 specify some special conditions of registration in the portal that do not affect the consultation of the information of interest, such as the potential suppliers that intend to participate in public procurement (ChileCompra, IMSS, PanamáCompra, SERCOP) and reporters of medicines purchases and prices of transactions (BPS, OPFP, SISMED). 


\begin{tabular}{|c|c|c|}
\hline Web Portal & Country & Access URL \\
\hline BPS, Health Price Database & Brazil & http://aplicacao.saude.gov.br/bps/login.jsf \\
\hline $\begin{array}{l}\text { CMED, Drug Market Regulation } \\
\text { Chamber }\end{array}$ & Brazil & http://portal.anvisa.gov.br/listas-de-precos \\
\hline $\begin{array}{l}\text { Chilecompra, Public Procurement } \\
\text { Portal }\end{array}$ & Chile & https://www.mercadopublico.cl/Home \\
\hline $\begin{array}{l}\text { IMSS, Mexican Social Security } \\
\text { Institute Procurement Portal }\end{array}$ & Mexico & http://compras.imss.gob.mx/?P=search_alt \\
\hline K@iros® & Argentina & http://ar.kairosweb.com/ \\
\hline $\begin{array}{l}\text { OPFP, Pharmaceutical Products } \\
\text { Observatory of Peru }\end{array}$ & Peru & http://observatorio.digemid.minsa.gob.pe/\# \\
\hline $\begin{array}{c}\text { Panamácompra, Public Procurement } \\
\text { Portal }\end{array}$ & Panama & $\begin{array}{l}\text { http://www.panamacompra.gob.pa/ambiente } \\
\text { publico/AP_BusquedaAvanzada.aspx }\end{array}$ \\
\hline SERCOP, National Public Procurement Service & Ecuador & $\begin{array}{c}\text { https://sicm.compraspublicas.gob.ec/Proces oContratacion/compras/PC/ } \\
\text { buscarProceso.c } \\
\text { pe?sg=1 }\end{array}$ \\
\hline $\begin{array}{c}\text { SISMED, Drug Price Information } \\
\text { System }\end{array}$ & Colombia & http://web.sispro.gov.co/ \\
\hline
\end{tabular}

Table 3: LA pricing and public procurement web portal access sites.

\section{Characterization of drug price data available on web portals}

Of the portals included in this study, the following are those whose nature is unrelated to ensuring transparency in the national public procurement. Their information is not related to the exact data of purchases of medicines, and show regulatory purposes for drug prices (BPS, CMED and SISMED), setting of reference values to induce offers (SERCOP) and publication of price catalogs reported by surveys of manufacturers or retailers (K@iros ${ }^{\oplus}$, OPFP) (Table 6).

Nature of the collected price data: Regarding the nature of collected price data, in the case of SISMED, due to regulation of medicines prices in Colombia, manufacturers, wholesalers and institutions providing health services, the average price, minimum and maximum purchase price of medicines by commercial presentation of each drug marketed in the country should be reported on a quarterly basis (Table 6).

In the case of BPS, the price collected is the fixed institutional purchase price during the corresponding period, which can be compared with a weighted average value established by Municipalities. This report is entered using the Brazilian national medicine code, namely, CATMAT, which offers a standardized drug identification in the previously described characteristics (Table 6).

A second Brazilian information portal (CMED) and another from Argentina (K@iros ${ }^{\varpi}$ ) collect prices for commercial presentation suggested by manufacturers based on surveys of the pharmaceutical industry. In the case of Brazil, this information collection has a regulatory purpose, and from this data, two price indices are established to regulate retail sales and public procurement. In the case of Argentina, K@iros ${ }^{\circledast}$ is shown as a price catalog of the pharmaceutical industry for public consultation (Table 6).

Finally, Peru's OPFP collects sales data from retailers (pharmacies), and Ecuador's SERCOP portal collects a reference price to induce drug offers in auction processes (Table 6).

Nature of the price data posted in portal: Two portals publish sales prices corresponding to the retail channel: Argentina's K@iros ${ }^{\circ}$ and Peru's OPFP. The former publishes the same prices suggested by the industry by survey as the final price to the public by commercial presentation; the latter publishes the prices reported by pharmacies and from these establishes a minimum reference price for public sector procurement. In this case, prices are established by pharmaceutical form and concentration (e.g. unit price per tablet / capsule of nifedipine 10 mg); although OPFP's internal search engine provides preset options by commercial brand, the price results it shows link all products that have the same composition, pharmaceutical form and concentration.

On the other hand, BPS Brazil and SISMED Colombia build price indices. The weighted average price of the former corresponds to the institutional channel established from the reports described in the previous paragraph. This index is constructed by Municipalities and for each CATMAT code, that is, for each drug identified by its composition, pharmaceutical form, route of administration and packaging of medication, without binding the commercial brand. In the case of Colombia, the price index corresponds to a quarterly weighted average price of all national reports made for each commercial brand, including its various commercial presentations. This value is constructed without discriminating reports from the industry, institutional channel and wholesalers (Table 6).

There are two portals that publish minimum or maximum reference prices for public sector purchases, namely: Brazil's CMED, besides publishing maximum prices for public procurement, publishes maximum prices of public sales. These lists are updated monthly and calculated from the price reported by the manufacturer for each commercial brand and its presentations (Table 7). On the other hand, Peru's OPFP publishes a minimum price for the public sector by pharmaceutical form and drug concentration without discriminating commercial brands, calculated from price data collected from retail pharmacies (Table 6).

Finally, SERCOP publishes unit prices per commercial presentation provided by Ecuador's Reverse Auction participants.

Date format and frequency of reported price: With the exception of Argentina's K@iros , all other portals report prices with standardized date formats. Regarding the price report frequency, CMED monthly updates its listings, SISMED has a quarterly report, BPS and OPFP show an irregular frequency and K@iros ${ }^{\oplus}$ and SERCOP specify it (Table 6).

Standardization of the medication's name: In all cases, except for Argentina's K@iros ${ }^{\oplus}$, the medicine's name is standardized in terms of its composition, concentration and pharmaceutical form. Only in the case of Brazil, both BPS and CMED standardize primary packaging (Annex 8). Only SISMED Colombia shows the Anatomical Therapeutic Chemical Classification (ATC) as an item to identify the medicine's composition and therapeutic action. 


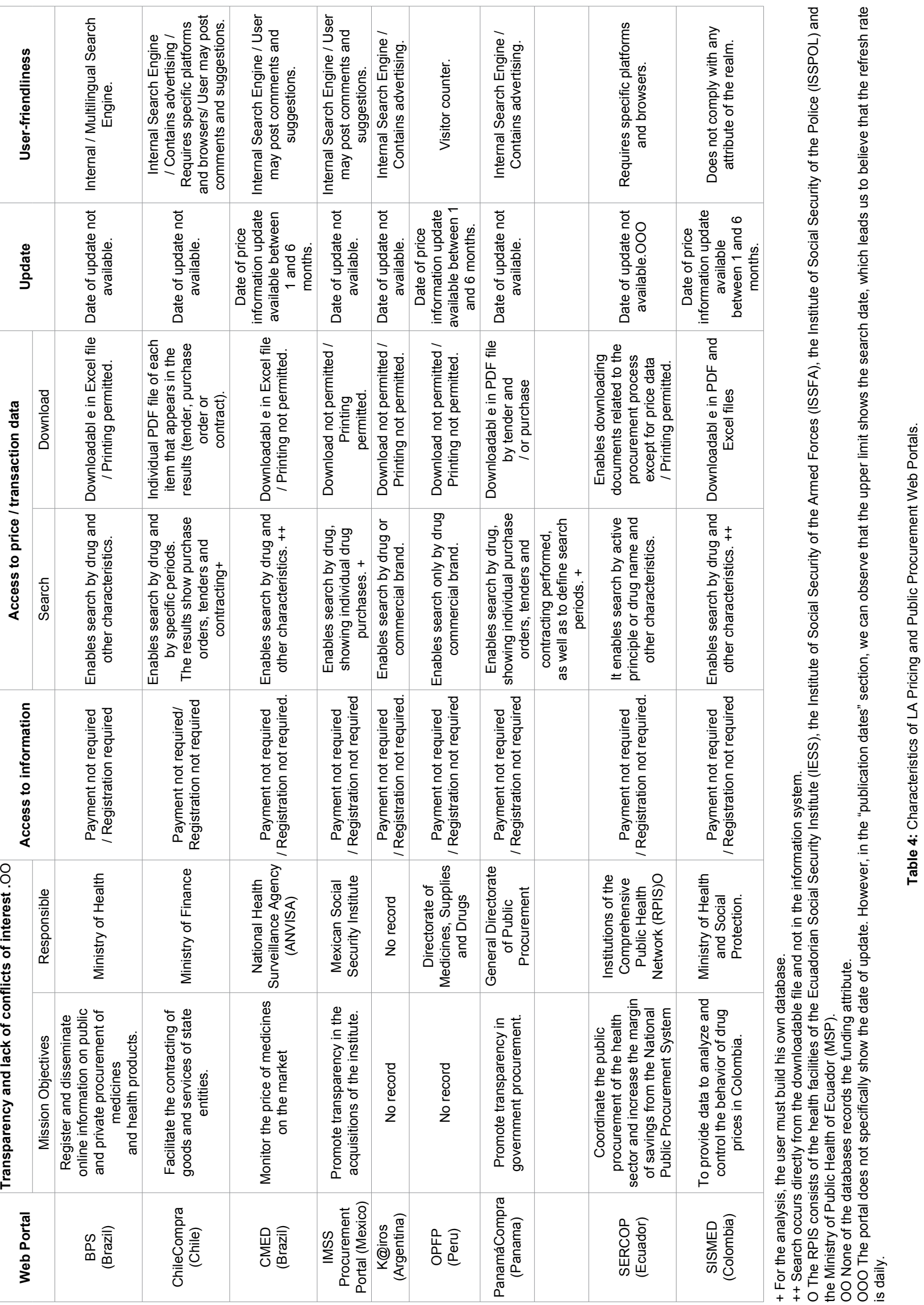


Citation: Acosta A, Basto S, Fonseca MF, Durán C, Vargas C, et al. (2018) Description of Drug Pricing and Procurement Information Web Portals in Some Latin American Countries. Pharmacoeconomics 3: 116. doi:10.4172/2472-1042.1000116

\begin{tabular}{|c|c|c|c|c|c|c|c|c|c|}
\hline \multirow{2}{*}{ Attributes } & \multicolumn{9}{|c|}{ Web Portals } \\
\hline & Chilecompra & PanamáCompra & $\begin{array}{c}\text { IMSS } \\
\text { (Mexico) }\end{array}$ & $\begin{array}{l}\text { SISMED } \\
\text { (Colombia) }\end{array}$ & $\begin{array}{c}\text { BPS } \\
\text { (Brazil) }\end{array}$ & $\begin{array}{c}\text { K@iros }{ }^{\circledR} \\
\text { (Argentina) }\end{array}$ & $\begin{array}{l}\text { OPFP } \\
\text { (Peru) }\end{array}$ & $\begin{array}{l}\text { CMED } \\
\text { (Brazil) }\end{array}$ & $\begin{array}{l}\text { SERCOP } \\
\text { (Ecuador) }\end{array}$ \\
\hline \multicolumn{10}{|c|}{ General Information } \\
\hline $\begin{array}{l}\text { Purpose of } \\
\text { collection }\end{array}$ & $\begin{array}{l}\text { Funding and } \\
\text { Distribution }\end{array}$ & $\begin{array}{l}\text { Funding and } \\
\text { Distribution }\end{array}$ & $\begin{array}{l}\text { Funding and } \\
\text { Distribution }\end{array}$ & $\begin{array}{l}\text { Funding and } \\
\text { Distribution }\end{array}$ & $\begin{array}{l}\text { Funding and } \\
\text { Distribution }\end{array}$ & Distribution & Distribution & $\begin{array}{l}\text { Funding and } \\
\text { Distribution }\end{array}$ & $\begin{array}{l}\text { Funding and } \\
\text { Distribution }\end{array}$ \\
\hline System's sector & Public & Public & Public & $\begin{array}{l}\text { Public and } \\
\text { Private }\end{array}$ & $\begin{array}{l}\text { Public and } \\
\text { Private }\end{array}$ & Private & $\begin{array}{l}\text { Public and } \\
\text { Private }\end{array}$ & $\begin{array}{l}\text { Public and } \\
\text { Private }\end{array}$ & Public \\
\hline Drug use scope & $\begin{array}{l}\text { Inpatient and } \\
\text { Outpatient }\end{array}$ & $\begin{array}{l}\text { Inpatient and } \\
\text { Outpatient }\end{array}$ & $\begin{array}{c}\text { Inpatient and } \\
\text { Outpatient }\end{array}$ & $\begin{array}{c}\text { Inpatient and } \\
\text { Outpatient }\end{array}$ & $\begin{array}{l}\text { Inpatient and } \\
\text { Outpatient }\end{array}$ & $\begin{array}{c}\text { Not } \\
\text { applicable }\end{array}$ & Outpatient & $\begin{array}{l}\text { Inpatient and } \\
\text { Outpatient }\end{array}$ & $\begin{array}{l}\text { Inpatient and } \\
\text { Outpatient }\end{array}$ \\
\hline $\begin{array}{l}\text { Requirements } \\
\text { users entering } \\
\text { information }\end{array}$ & $\begin{array}{l}\text { Prior } \\
\text { registration } \\
\text { required }\end{array}$ & $\begin{array}{l}\text { Prior registration } \\
\text { required }\end{array}$ & $\begin{array}{l}\text { No prior } \\
\text { registration } \\
\text { required }\end{array}$ & $\begin{array}{l}\text { Prior } \\
\text { registration } \\
\text { required }\end{array}$ & $\begin{array}{l}\text { Prior } \\
\text { registration } \\
\text { required }\end{array}$ & $\begin{array}{c}\text { Not } \\
\text { applicable }\end{array}$ & $\begin{array}{c}\text { Not } \\
\text { applicable }\end{array}$ & Not applicable & $\begin{array}{c}\text { Prior registration } \\
\text { required }\end{array}$ \\
\hline
\end{tabular}

Table 5: General Information available on LA pricing and public procurement web portals.

\begin{tabular}{|c|c|c|c|c|c|c|}
\hline \multirow[b]{2}{*}{ Attributes } & \multicolumn{6}{|c|}{ Web Portals } \\
\hline & SISMED (Colombia) & BPS (Brazil) & $\begin{array}{c}\text { K@iros } ®+ \\
\text { (Argentina) }\end{array}$ & OPFP (Peru) & CMED (Brazil) & SERCOP (Ecuador) \\
\hline \multicolumn{7}{|c|}{ Price information } \\
\hline $\begin{array}{l}\text { Nature of the } \\
\text { collected price } \\
\text { data }\end{array}$ & $\begin{array}{c}\text { Average price / Maximum } \\
\text { price / Minimum price } \\
\text { (Manufacturer, } \\
\text { wholesaler, institutional) }\end{array}$ & $\begin{array}{l}\text { Institutional purchase } \\
\text { price }\end{array}$ & $\begin{array}{l}\text { Price to the public } \\
\text { suggested by the } \\
\text { manufacturer * }\end{array}$ & $\begin{array}{l}\text { Sale price in pharmacy } \\
\text { (Unit price per - } \\
\text { pharmaceutical form - } \\
\text { concentration) }\end{array}$ & $\begin{array}{l}\text { Maximum sale price of the } \\
\text { manufacturer }\end{array}$ & $\begin{array}{c}\text { Price per unit } \\
\text { of medication } \\
\text { established by the } \\
\text { public contractor at } \\
\text { the beginning of the } \\
\text { auction ** }\end{array}$ \\
\hline \multirow[t]{2}{*}{$\begin{array}{c}\text { Nature of the } \\
\text { price data } \\
\text { published in the } \\
\text { portal }\end{array}$} & $\begin{array}{l}\text { Average price / Maximum } \\
\text { price / Minimum price } \\
\text { (Manufacturer, } \\
\text { wholesaler, institutional) } \\
\text { (Unit Price per } \\
\text { commercial presentation) }\end{array}$ & $\begin{array}{c}\text { Weighted average price } \\
\text { Weighted by Reporting } \\
\text { Municipality } \\
\text { Unit price per } \\
\text { concentration - } \\
\text { pharmaceutical form } \\
\text { - package - quantity } \\
\text { contained, Code } \\
\text { CATMAT }\end{array}$ & $\begin{array}{l}\text { Unit Price per } \\
\text { commercial } \\
\text { presentation* }\end{array}$ & $\begin{array}{l}\text { Sale price in pharmacy } \\
\text { (Unit price per } \\
\text { pharmaceutical form - } \\
\text { concentration) } \\
\text { Minimum price for the } \\
\text { Public Sector }\end{array}$ & $\begin{array}{c}\text { Maximum sale price to } \\
\text { the public by commercial } \\
\text { presentation** } \\
\text { Maximum price for } \\
\text { public procurement by } \\
\text { commercial presentation }\end{array}$ & $\begin{array}{l}\text { Unit Price per } \\
\text { commercial } \\
\text { presentation }\end{array}$ \\
\hline & & & Not specified & Variable ${ }^{* * *}$ & & \\
\hline $\begin{array}{l}\text { Price report } \\
\text { frequency }\end{array}$ & Quarterly & Variable & $\begin{array}{c}\text { (It is only possible to } \\
\text { consult the price in } \\
\text { force at the date of } \\
\text { consultation) }\end{array}$ & $\begin{array}{c}\text { (It is only possible to } \\
\text { consult the updated } \\
\text { price) }\end{array}$ & Monthly & Not specified \\
\hline $\begin{array}{l}\text { Price data date } \\
\text { format }\end{array}$ & Standardized & Standardized & Not reported & Standardized & Standardized & Standardized \\
\hline Drug Name & $\begin{array}{c}\text { ATC, INN } \\
\text { and Trade Name }\end{array}$ & $\begin{array}{l}\text { INN (CATMAT national } \\
\text { code) }\end{array}$ & $\begin{array}{c}\text { INN and Commercial } \\
\text { Name }\end{array}$ & $\begin{array}{l}\text { INN and Commercial } \\
\text { Name }\end{array}$ & $\begin{array}{l}\text { INN and Commercial } \\
\text { Name }\end{array}$ & INN \\
\hline
\end{tabular}

* Price reported by surveys to manufacturers.

** Prices established by regulation / prices established to induce offers in auctions.

*** Variable by report.

+ It does not standardize the description of pharmaceutical form nor concentration of the medicine. None of the portals standardizes the packaging's characteristics. Table 6: Characterization of drug price data available on web portals.

\section{Characterization of data of public procurement of medicines available on web portals}

Some web portals in Latin America are public procurement sites (BPS/SIASG, Chilecompra, Panamácompra and SERCOP). They administer state public tenders platforms, through which state agencies make their purchases and contracts, make transparent processes of acquisition of products and services that allow their proper functioning thereof. These purchases range from office supplies, medicines and food to transportation services or consultancies.

On the other hand, there are institutional procurement portals like the IMSS that seek to make Social Security of Mexico's procurement processes transparent.

Nature of the transaction data collected and published: In most cases, data collected were characterized as values of public institutional procurement (BPS/SIASG, Chilecompra, IMSS and Panamácompra). In the case of BPS/SIASG, it is possible to find values of private institutional purchases, a voluntary reporting in Brazil, and in the case of Ecuador, the value collected is the price offered by state institutions to induce a medicines procurement process known in Ecuador as "Reverse Auction" (Table 7).

As for the values of public procurement transactions published in these web portals, apart from the price or total purchase value, in some cases, the purchase unit value (BPS/SIASG, Chilecompra, IMSS) is specified. In the case of Ecuador, SERCOP publishes the result of the Reverse Auction process, which are possible transaction values taking into account the required volume of drugs and the lowest bids obtained within the process (Table 7). 


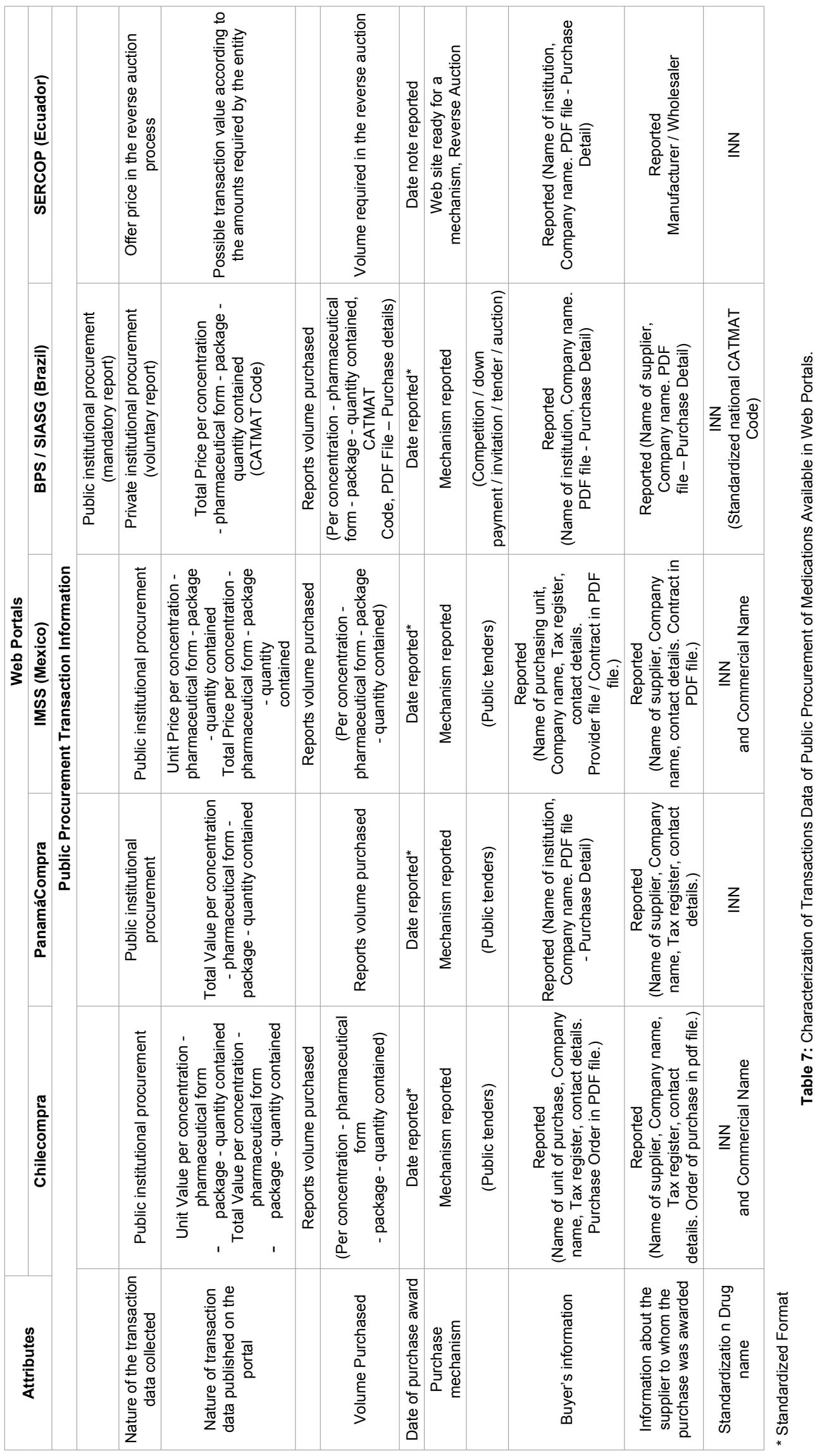


The BPS/SIASG has a great advantage over other portals because it allows downloading institutional procurement transactions for a long period (2004-2016), if SIASG data inclusion is selected the initial search. In the case of portals such as Chilecompra and Panamácompra, the search for information requires more effort from the user, as the initial report of purchase transactions does not display the purchase value as first option. Access to this information requires accessing the link that shows each record resulting from the search.

It also does not show pre-established criteria for the search for information, as is the case of BPS, where it is possible to search by active principle, composition and pharmaceutical form, which are standardized characteristics in the Brazilian CATMAT code. These two situations significantly affect the portal's user-friendliness.

The same situation described for Chilecompra and Panamácompra is seen in IMSS Mexico. Accessing information on the purchase value and the price per unit requires consulting the purchase form of each record delivered by the main search engine. This query is made possible by entering part of the drug name, since the portal has preset search options. In turn, in the purchase tab, it is possible to consult the total amount of the last purchases made with the same product description.

Finally, Ecuador's SERCOP shows the description of the processes of contracting once the reverse auction is completed, including the reference value achieved for the volume demanded. The published information includes PDF files corresponding to the entire purchase process, including the auction's negotiation stages and the invoice of the final purchase transaction.

Detailed information about the purchase: One of the portals with more standardized information regarding the type of purchase is Brazil's BPS/SIASG, which allows classifying the type of purchase according to a pre- established portal categorization (Competition / downward price correction / invitation / tender / auction). For the other cases, except SERCOP (reverse auction), the purchase mechanism are public tenders (Table 7).

In most cases, the purchase date is reported in a standardized way, and in all cases it is possible to consult the volume of drugs purchased (Table 7).

Buyers and suppliers identities are always available in purchase orders or invoices (PDF files). In these files, it is possible to consult information, such as contact details, corporate name and tax register (Table 7).

Drug name standardization: Brazil's BPS/SIASG standardizes the drug's name in terms of its composition, concentration, pharmaceutical form and primary packaging. This allows making more robust consultations as previously described. In all other cases, it is possible to consult the medicine's name by INN and commercial brand. The latter, in particular, is found in PDF files of invoices or purchase orders (Table 7).

\section{Discussion}

Several of the portals described are being used to make international price comparisons. Therefore, it is relevant to analyze the characteristics of websites, the information they provide and medicines price and transactions data, since both aspects can facilitate or limit the usefulness of these sources of information in comparative studies [5].

In terms of transparency, a high percentage of portals meet the quality criteria that help the user to detect potential conflicts of interest through the consultation of mission objectives, responsible and author. In addition, all sites allow direct contact with the webmaster, possibly facilitating researchers' consultation with the administrator on the methodological aspects of the information source.

With respect to the user-friendliness of the analyzed portals, a great variability is observed. Attributes such as a search engine in the price data, possibility of downloading or printing determine the easy consultation and use of the information reported. The results obtained in "access to price and transaction data" allow clear advantages of information sources such as Brazil's BPS, with two access options, such as general public consultation and as a database registered user.

For the first case, the national CATMAT code categorizes and standardizes the description of Brazilian drugs by active principles, composition, concentration and pharmaceutical form (e.g. acyclovir, $200 \mathrm{mg}$ and tablet). These searches are predetermined by the CATMAT information hierarchy. In some cases, other characteristics that are also predetermined by the website may be added, such as primary packaging classes by medicine, and generic and branded products can be disaggregated; For the second case of registered user, also allows access to data of Brazil's Public Procurement Integrated General Services Administration System (SIASG), also pre-established by the CATMAT, also allows access to periods of public procurement since 1997.

Combining the results shown for user-friendliness and characteristics of web portals that are part of this level of information, it is worth highlighting the versatility of search criteria provided by portals such as the Brazilian BPS and Peruvian OPFP, which, apart from adding information about prices and data of transactions of public procurement of medicines by composition and pharmaceutical form of drugs independent of commercial brands, allow the addition of information by criteria, such as national geopolitical divisions, type of establishment, manufacturer name, pharmacy name, purchase type, classification of generic drugs, among others.

In the case of public procurement transactions portals, with the exception of Mexico's IMSS, the search engine available in Chilecompra and Panamácompra websites does not offer preset possibilities to complete the terms that are entered, this supposes greater difficulty of use of the sources and also one cannot be sure that results shown by the search engine cover all those records that the user wants to consult given the lack of standardization in the drug identification. Another issue that does not facilitate the use of procurement information in these portals is the difficulty of adding information and downloading it, since it requires that each purchase data be accessed manually and data exported to an external template.

The only portals that allow downloading information in EXCEL template or PDF format are BPS Brazil and SISMED Colombia. In the first case, data correspond to purchases made in user pre-established periods, for a maximum of 10 years. It is the best source that offers swift access to data with which it is possible to build time series of up to 10 years per drug. In the second case, it is possible to download the information in EXCEL template. Unlike the BPS, only the latest published price data is available and it is not possible to download information for specific periods. A standardized drug identification element allows, in the case of Colombia, conducting aggregated consultations by therapeutic or pharmacological groups according to the ATC code levels. This advantage quickly provides expenditure and consumption information by groups of drugs related to ATC hierarchies, e.g. Statins. SISMED is the only portal that allows adding information of medicines prices by ATC levels. 
An advantage of all public procurement transactions portals is that information that accompanies the purchase value is very complete, since it allows identifying both the buyer and the client, as well as volumes of drugs per transaction. These data are much more accurate as pharmaceutical expenditure estimation data than price indexes constructed from periodic weighted averages (SISMED), theoretical indexes constructed for the purpose of regulation of commercialization channels (CMED) or data of suggested prices to the public collected from surveys of pharmaceutical product holders (K@iros ${ }^{\circledR}$ ).

Prices such as those published in CMED Brazil and K@iros Argentina do not match the actual transaction price - it is difficult to know the price actually paid for a drug due to the often-confidential discounts granted by companies to many buyers. Thus, in Argentina, it is impossible to recognize from K@iros ${ }^{\oplus}$ the behavior of actual transactions in the pharmaceutical markets. In both cases, the only reporting parties are holders of pharmaceutical products.

The multilingual nature was only considered in the design of a website. While the main intention of these portals is to share information nationwide, this attribute could be improved in other portals, increasing the possibility of consulting non-Spanish speaking users.

Eight of the nine portals belong to governmental entities such as ministries, public procurement centers or drug regulatory agencies. Portals such as BPS provide visibility and transparency of the use of the Unified Health System (SUS) funds. Thus, each public institution plays its role of social control and monitoring of public management. Other sectors of society are also benefited and use the information available for various consultations and studies.

\section{Conclusion}

This study shows that access to the analyzed web portals is free, the information can be consulted without payment and, in some cases, is downloadable and allows the search according to user requirements. Therefore, we can be establish that there are currently sources of information in the region that can be input of information for policy decision and for studies of drug consumption and expenditure.

Most of these sources report funding and distribution of medicines in countries such as Argentina, Brazil, Colombia, Chile, Ecuador, Mexico, Panama and Peru, three of them collect information only from the public sector and the others do so for both sectors. For all cases, with the exception of Peru, drugs for both inpatient and outpatient use are included.

Sources of information reporting data on public drug transactions are comparable across all attributes analyzed. They identify whether the drug supplier is the manufacturer or wholesaler, the date, volume and the purchase mechanism. These data increase the transparency of transactions carried out by health institutions, allow quantifying an approximate drug consumption figure in the institutional context and in the public sector.

Similarly, when reporting purchase value, studies can be made that calculate a proxy for institutional and public sector spending.

Given the public nature of most portals, no case requires payment or registration to access the information portal. There are some portals that, due to their nature of public contracting portals, show different levels of access and data load.

The characterization carried out increases the transparency of information on medicines prices to contribute to the decision-making of Latin American governments regarding negotiations on the purchase of pharmaceutical products, fixing and constructing the international reference price and price adjustments of already regulated medicines.

The level of standardization in the technical characteristics that define the pharmaceutical product, the name of the drug can be found in all databases under the International Nonproprietary Names, which facilitates data management in comparative studies, standardization is observed in the way databases report the concentration, describe the pharmaceutical form and quantify the units by commercial presentation.

Within the Latin American context, this investigation represents the first approximation in the characterization of some sources of information of medicines prices. In the same vein, it allows to establish findings to strengthen mechanisms that allow the design and development of comparative studies in the region.

This study showed that the analyzed sources of information of prices and public procurement could be used to develop studies of distribution of medicines in the public and private sector. The quality analysis of websites in Latin America is a relevant factor, since they are sources that allow developing comparisons of international prices of medicines. Therefore, we recommend implementing cooperative efforts that reduce the variability of the presented data and avoid bias when comparing information.

The promotion of sources of public information on drug prices, expenditure and consumption in LA allows identifying trends, comparisons and (causal) associations that can inform drug policies implemented in the Region.

Some authors, such as Hoebert et al. [8], mention the low availability of data from the hospital sector, even in high-income countries. This may explain why most of the comparative studies in LA have been restricted to the commercial sector.

Medicines delivered at the institutional level represent a significant percentage of the total products distributed in a country, so researchers should be encouraged to use data sets that are even closer to hospital consumption. Thus, sources of information such as BPS, Chilecompra, Panamácompra, SERCOP and SISMED provide the user with more accurate information and their results could complement the efforts made so far.

\section{Recommendation}

To improve the interpretation of price data, it is recommended that websites publish documents that describe in detail the components of each price (for example, whether or not VAT is included and, if so, the tax amount). It is important for researchers to know the reported price structure beforehand to evaluate the limitations associated with comparing prices collected from different stakeholders of the distribution chain. Carrying out price analyses in the same subcategory will reduce study bias, especially in cases where the International Reference Price is to be determined [13]. An irregular frequency with which price data are collected and reported is also observed, a factor that may hamper the development of comparative time series studies. To improve data interpretation, it is recommended that websites publish information on price components. If data is built through surveys, it is convenient to report the collection source and its share of representativeness.

Technical standardization reduces the incorrect pricing bias 
Citation: Acosta A, Basto S, Fonseca MF, Durán C, Vargas C, et al. (2018) Description of Drug Pricing and Procurement Information Web Portals in Some Latin American Countries. Pharmacoeconomics 3: 116. doi:10.4172/2472-1042.1000116

Page 10 of 10

associated with the comparability of two commercial presentations of different sizes and concentrations, among others. The desirable identification of the medicine should, in all cases, be through its INN name and not its commercial brand; it is recommended that databases analyzed include in their data the ATC drug code as it increases the level of comparability and facilitates price analyses by therapeutic group.

According to websites described for the Region, it is worth establishing that, for the purposes of medicines price regulation policies and purchasing policies, it would be desirable to adjust prices in other currencies by the exchange rate at the date of the transaction, and not by PPP (Purchasing Power Parity). It is also necessary to estimate the convenience of being able to calculate price indices (for example, the trend of statins prices), which requires information on quantities sold in each transaction at a certain price.

Websites that report public procurement should include variables that can explain or justify price variations (transaction volume, packaging size, payment terms, etc.). Likewise, it would be ideal for the purpose of transactions transparency to report discounts, trade-offs in other goods, etc.

Researchers and decision-makers must work together to establish national data collection systems to accurately describe drug use in LA countries, so that data are also valid for cross-country comparisons.

A number of LA countries collect institutional procurement data. This would allow developing studies comparing data from sources collecting information on public procurement versus data provided by IMS Health. This will allow detecting differences in the volumes of sales and prices granted by the wholesaler to the institutional and commercial channel.

Drugs delivered at the institutional level correspond to a significant share of total products distributed in a country, so researchers should be encouraged to use data sets that are even closer to hospital consumption. Thus, sources of information that report public procurement provide user with more accurate information and their results could complement the efforts made so far. However, it is more convenient to use prescription databases for the design of drug use studies in the institutional sector because they allow a closer approximation of individualized real consumption.

Priority should be given to collecting drug consumption data from the public sector. Once public sector information in LA is available, its combination with private sector data would allow for more comprehensive estimates of drug use in a consistent longitudinal perspective. Therefore, evaluating the proposed framework for assessing data generated from different sources in the same country will be a major research challenge for the future.

\section{Acknowledgement}

This work would not have been possible without the dedication and efforts by authors without specific funding. Brian Godman and Bjorn Wettermark (Karolinska Institutet) provided the initial references and inputs that started this project. Guillermo Bramuglia (Faculty of Pharmacy and Biochemistry, University of Buenos Aires, Argentina) allowed the development of the project as part of the doctoral project of the first author. Oscar Bernal (School of Government Alberto Lleras Camargo - University of Los Andes, Colombia) for his advice and guidance for the thesis project of SB and MF.

\section{References}

1. Machado M, O'Brodovich R, Krahn M, Einarson TR (2011) International drug price comparisons: quality assessment. Pan Am J Public Heal 29: 46-51.

2. Acosta A, Ciapponi A, Aaserud M, Vietto V, Austvoll-Dahlgren A, et al. (2014) Pharmaceutical policies: effects of reference pricing, other pricing, and purchasing policies. Cochrane Database Syst Rev 10: CD005979.

3. Andia T, Gaviria A, Gomez C, Jaramillo LF, Marquez S, et al. (2014) First Evaluation of Colombia's External Reference Pricing System. Value in Health 17: 15.

4. Danzon PM, Kim J (1998) International Price Comparisons for Pharmaceuticals: Measurement and Policy Issues. Pharmacoeconomics 14: 115-28.

5. Van Dongen MS (2010) Websites reporting medicine prices: a comparative analysis. Geneva.

6. Acosta A, Rodríguez I, Tobar F, Vaca C, Villardi P (2011) Guía de fuentes de información de precios de medicamentos en América Latina. Guía de fuentes de información de precios de medicamentos en América Latina.

7. Hinsch M, Kaddar M, Schmitt S (2014) Enhancing medicine price transparency through price information mechanisms. Global Health 10: 34

8. Hoebert JM, Mantel-Teeuwisse A, Van Dijik L, Laing R (2011) Quality and completeness of utilisation data on biological agents across European countries: tumour necrosis factor alpha inhibitors as a case study In: Crosscountry variation in medicines use; a pharmaceutical system perspective. Pharmacoepidemiol Drug Saf 20: 65-71.

9. Walley T, Folino-Gallo P, Schwabe U, Van Ganse E, Stephens P (2004) Comparison of national administrative and commercial databases to monitor expenditure and costs of statins across Europe. Eur J Clin Pharmacol 60: 503511.

10. Domínguez-Castro A, Iñesta-García A (2004) Evaluación de la calidad de las webs de centros de farmacoeconomía y economía de la salud en Internet mediante un cuestionario validado. Gac Sanit 18: 295-304.

11. Stichele V, Elseviers M, Ferech M, Blot S, Goossens H, et al. (2004) European Surveillance of Antimicrobial Consumption (ESAC): Data Collection Performance and Methodological Approach. Br J Clin Pharmacol 58: 419-428.

12. Acosta A, Tobar F, Vaca C, Villardi P (2012) Guía de fuentes de información de precios de medicamentos en América Latina 2014.

13. Tobar $F$ (2014) Por qué las Enfermedades Catastróficas son un problema? Concepto, Impacto. In: Guemes F. Fundación Sanatorio Guemes. 